\title{
軸線の見通しから評価した大中の湖干拓地における景観構成の特徴
}

\section{Characteristics of landscape evaluated from perspectives of axes in Dainaka-no-ko lagoon drained land}

\author{
西村 成貴* 村上 修一* 轟 慎一*
}

\author{
Shigeki NISHIMURA Shuichi MURAKAMI Shinichi TODOROKI
}

\begin{abstract}
The objectives of this paper were to clarify characteristics of landscape in Dainaka-no-ko lagoon reclaimed land located on the coast of Lake Biwa. Based on the arrangement of roads, canals and fields constructed by the reclamation project, it was predicted and examined that the landscape centered on the axis would be viewed from the surrounding levees. Viewpoints were set at 79 points of intersection of the roads and the drainage canals with the levees. At each point, planar composition of roads, canals, fields and the other elements, situation of surrounding geography, sectional structure relating to the reclaimed land and the adjacent topography, and composition of landscape viewed from the levee were surveyed and analyzed through investigation of both literature materials and maps and field work. As a result, the characteristics that the axis of the road or the drainage canal was at the center, and the fields were lined up on both sides were clarified. Such character of line symmetrical landscape along the axis was weakened by buildings and other elements. Gradient changes that caused the optical illusion effect pointed out in the research of the French garden was also seen in this reclaimed land. It also turned out that there were possibilities of improving the value of such landscape by introducing the landscape design which took advantage of the axes.
\end{abstract}

Keywords: lagoon, coastal zone, rural landscape, landscape value, symmetry, grid キーワード：内湖，沿岸域，農村景観，景観価值，対称性，格子

\section{1. 背景と目的}

国内では，海や湖などの水域を構造物でしめきり陸域にする干 拓によって，農地が増やされてきた 1)。近代以前の干拓地につい ては，その造成をとおして土地の形状に現れた景観の特徴が，既 往研究によって明らかにされている 2),3)。一方，近代には，食料 増産の政策や技術の進歩を背景に，全国各地で大規模な干拓が行 われた4)。近代の干拓地の景観については，これまで，景観に配 慮した水路護岸や樋門のあり方 5), 6), 7)，干拓地および周辺の現存 植生に着目した湿地環境復元の可能性 ${ }^{8)}$, 干拓地に植栽された樹 木の形状に着目したジオパークとしての活用の可能性 ${ }^{9)}$, 潟湖の 干拓による景観の変化 ${ }^{10)}$, 内湖 11) の干拓による景観や生活の変 化 ${ }^{12)}{ }^{13)}$ ，内湖の干拓が地域制公園の指定におよぼした影響 ${ }^{14)}$, が 既往研究によって明らかにされている。

さらに，八郎潟干拓地の農村建設事業においては，緑地計画に よって意図的に景観の形成が行われた ${ }^{15)}$ 。その内容は, 農家の庭, 各種の公園や広場が設けられ，緑道によって連結され，防風林に よって取り囲まれるというものであった 16)。防風林については, 直線状の幹線道路や地区内幹線道路の両側に幅 $30 \mathrm{~m}$ の緑地帯を とる形で計画されたが，そこには景観を形成する意味もあったと いう 17)。つまり，道路沿いに樹木が並ぶという，軸線を強く意識 させる特徵的な景観が意図的に形成されたことがわかる。一方, 幹線以外の道路や水路という直線状の要素や, 圃場という矩形の 要素も整備されたが, 緑地計画の中にそれらの記述はなく，軸線 を意識させる景観の形成にどのように位置づけられたのかは不明 である。

琵琶湖沿岸域では, 1943 年から 1971 年までの間に, 15 の内 湖に対して干拓が行われ 18), 干拓地の総面積は約 2,500ha におよ ぶ 19)。その中で最大の面積（1,145ha）を有するのが，大中の湖 干拓地である。文献資料 20) によれば，大中の湖干拓地の造成の 概要は以下のとおりである。周囲に堤防と承水溝 21$)$ を築き，干 陸化した湖底に 1 区画 $125 \mathrm{~m} \times 40 \mathrm{~m}$ の圑場を配した。揚水ポンプ
で排水し湖面より低い土地を維持するとともに，承水溝から灌溉 用水を導水するようにした。中央部に幹線排水路を開削して支線 排水路を $250 \mathrm{~m}$ ごとに直交させ， $250 \mathrm{~m}$ ごとに道路と用水路を配 した。さらに，入植者の住宅 216 戸を 3 ヶ所に分けて配置した。 なお，大中の湖干拓地においては，八郎潟干拓地のような緑地計 画は導入されなかった。

このような造成の結果は，特徽的な土地の形状となって現れて いる。大中の湖干拓地における堤防，承水溝，固場，排水路，道 路, 用水路, 入植者の住宅は, 現在, 図一1のようになっている。 周囲の堤防より低い平坦な土地に，固場，排水路，道路，用水路 が格子状のパターンを形成している。つまり，道路や水路という 直線状の要素が景観の軸線を成し，軸線の両側に圑場が並ぶ，と いう特徵的な景観が，堤防上より眺望されるとの予想が成り立つ (図-2)。

軸線を中心と寸る景観については，これまで，庭園 22)，23，都 市公園 24), 25)，都市 26）を対象として研究が行われてきており，特 定の空間や都市の優れた景観として, 一定の評価がなされている。 庭園においては, 17 世紀中頃に生まれたヴォー・ル・ヴィコント 庭園をはじめとしたフランス式幾何学庭園にて，軸線の技法が用 いられている。この庭園においては, 城館の前庭に軸線が配され， 更に軸線を成す平坦部が約 $1.5 \%$ と約 $0.3 \%$ の 2 とおりの公配を持 つことが明らかになっている 27)。同時に，この中折れにより遠く のものが近くに見えるという視覚効果を生み出していたことも判 明している。次第に，庭園に用いられた軸線の技法は，都市空間 へと用いられることとなる。都市公園においては, ブリュッセル のモン・テザール公園整備にて, 平面計画に軸線が用いられ, ま た視覚補正の技術が取り入れられている。また, 都市軸の構成に も軸線技法は影響を与え，パリのシャンゼリゼでは，庭園の軸線 を延長することで並木道へと発展したという例がある 28 )。

干拓地は，低平地ゆえ，水害に対して脆弱である。頻発する異 常気象に加えて, 排水設備をはじめとする農業基盤の管理や更新 

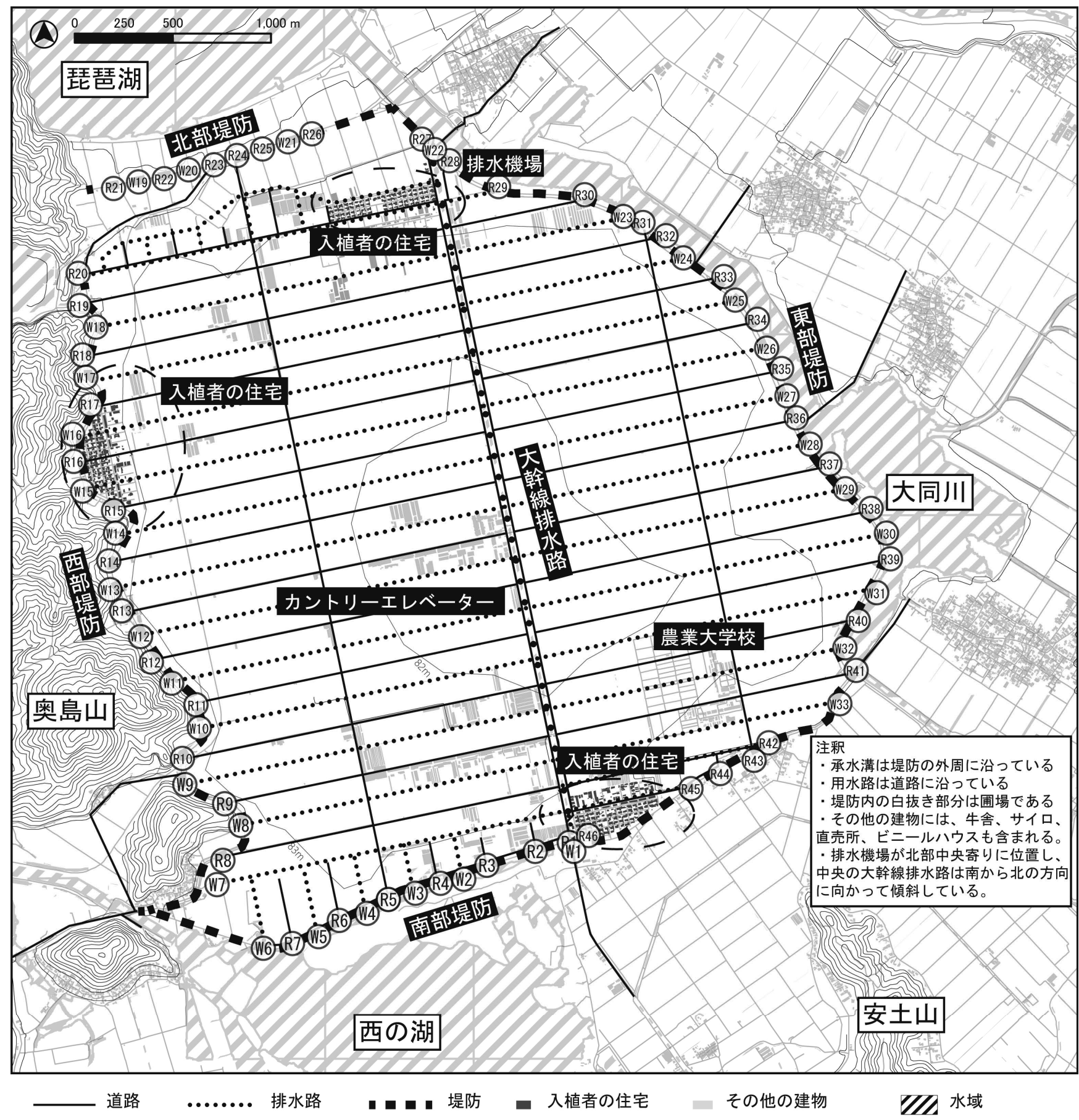

図-1 大中の湖干拓地の概要と視点の設定

にかかる費用の増大も予想される。食料生産の場としての農地に 対する社会的要請も，干拓地が造成された当時とは異なる。農業 のあり方の変革期において，干拓地の特徵を活かした観光のあり 方が地域で検討されるなど ${ }^{29)}$, 多面的な価值を探る動向が認めら れる。価值の向上という点では，未だランドスケープのデザイン コードを持たない干拓地においても，後からそれを導入すること により価值を向上させる機会があると考えられる。緑地計画が行 われなかった干拓地においても，軸線を中心とする景観を特徵と して明らかにすることができれば，結果的に軸線構成のデザイン コードを導入することができ，多面的な価值の創出の一助になる と考えられる。

このような価值の発現には，一般の来訪者によって眺望され得 ることが前提となる。図一 1 より，軸線を中心とする景観の予想 される視点は干拓地内にも存在すると考えられるが，農作業に対
する支障が想定されるため, 干拓地内で一般の来訪者の眺望を想 定した視点を設定し評価することは非合理的である。一方，外周 の堤防上には一般の来訪者も通行可能な道路があり, 干拓地より 高所にあって見通しがききやすいと考えられることから, 堤防上 の眺望を前提とすることが合理的である。したがって, 本研究で は, 大中の湖干拓地を対象として, 周囲の堤防上より眺望される, 軸線を中心とする景観の特徴を明らかにすることを目的とする。

\section{2. 研究方法}

大中の湖干拓地の眺望景観について，はじめに視点を設定し， 既往研究 ${ }^{30}$ をを参考に, 干拓地の道路, 水路, 圃場などの平面構 成と周囲の地理的状況，次に干拓地や周囲の地形に関わる立体構 成，そして堤防上から眺望される景観の構成について, 文献資料 や地図の調査および現地踏査の結果を分析し，軸線を中心とする 


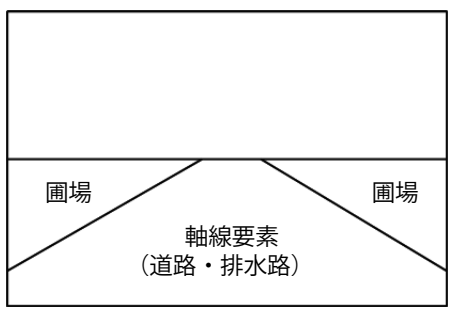

図一2 大中の湖干拓地における軸線景観の予想図

景観の特徵を考察した。

視点の設定においては，軸線の要素として干拓地の道路と排水 路を対象とした。用水路は道路に沿う形で設けられており道路と 一体化していることから, 独立した軸線の要素とみなせないため, 本研究では対象外とした。図一1のように，干拓地の道路および 排水路と堤防との交点 79 ケ所に視点を設定した。内訳は，道路 を軸線とする視点が 46 ケ所 (R1-R46)，排水路を軸線とする視 点が 33 ケ所 (W1-W33) である。なお, R21-R26, W19-W21 については，道路や排水路と堤防が離れていたため，それらの延 長線と堤防との交点に視点を設定した。

平面構成については，現地踏査で道路，排水路，圃場，入植者 の住宅，堤防，その他の要素の現況を把握するとともに，電子国 土 Web ${ }^{31)}$ にて, 道路や排水路の長さを計測した。加えて, 予想 図（図一2）のように，両側に圃場のある部分の長さも，道路や 排水路ごとに計測した。さらに，現地踏査や地図の読み取りをと おして，干拓地周囲の地理的状況を把握した。

立体構成については, DEM5m メッシュのデータ 32)を用いて, 設定した 79 ケ所の視点における堤防の標高，道路およひ排水路 の最高点と最低点の標高を計測し，道路および排水路の勾配を算 出した。また, 視点の高さを堤防の路面上 $1.5 \mathrm{~m}$ として, 道路や 排水路に沿う水平な視線を想定し, その視線が当たる要素（アイ ストップ）の有無を現地にて把握した。アイストップが有った場 合には, その要素の種類を記録し, 電子国土 Web にて視点から の距離を計測した。無い場合には，地図上で視線を延長し干拓地 周囲のアイストップの種類と視点からの距離を計測した。さらに, 堤防の標高と道路や排水路の最低点の標高差である比高を求めた。

堤防上から眺望される景観の構成については，以下のように調 查分析を行った。設定した 79 ケ所の視点において，干拓地側の 堤防端に立ち, 路面より $1.5 \mathrm{~m}$ の高さにカメラを据え, 道路ない し排水路の消失点が画面の中心に位置するように写真を撮影した 33)。撮影した写真を Adobe Illustrator CS6 で読み込み，道路， 排水路, 圃場, 建物, 建物以外の構造物, 樹木 - 山塊といった, 景観を構成する要素をトレースした（図一-3)。その上で，軸線の 要素の違い, 軸線が見通せる程度, 軸線の両側の圃場の配置の違 いにもとづき， 79 の眺望景観を分類した。

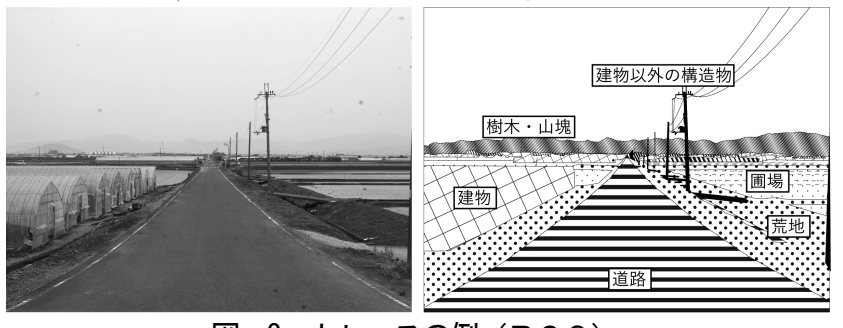

図-3 トレースの例（R20）

\section{3. 結果}

\section{（1）干拓地の平面構成と周囲の地理的状況}

琵琶湖干拓史 ${ }^{34)}$ とよると, 干拓の際にまず東西南北の各方角に, 南部堤防 (R1-R7, R42-R46, W1-W6, W33), 西部堤防 (R8-R20,
W7-W18) 北部堤防 (R21-R26, W19-W21), 東部堤防 (R27-R41, W22-W32) の 4 つの堤防が築かれた。中央に大幹線排水路が設 けられ，これと直交する支線排水路が $250 \mathrm{~m}$ ごとに設けられた。 また，大幹線排水路の両側と，その左右 $1 \mathrm{~km}$ のところに，4本の 南北幹線道路が造られ，これらに直交する 14 路線の支線道路が $250 \mathrm{~m}$ ごとに設けられた。道路の幅員は，大型機械の通行を考慮 して幹線道路が $6.5 \mathrm{~m}$, 支線道路が $5.5 \mathrm{~m}$ 及び $4.5 \mathrm{~m}$ と規定された。 また，農業の近代化を図り大型機械による営農が行えるように, 固場の大きさは，長辺 $125 \mathrm{~m}$ ，短辺 $40 \mathrm{~m}$ の $0.5 \mathrm{ha}$ と定められた。 つまり，排水路と用水路の併設された道路とが，交互に $125 \mathrm{~m}$ 間 隔で南北方向に並んでいる。一方，大中の湖干拓地には，216 世 帯が入植した。入植者の居住する集落が，北部，西部，南部の 3 ヶ所に，それぞれ 72 戸集団で造られた。また各集落の近辺には 牛を飼育する牛舎があり, 干拓地の中央には作物を集積するカン トリーエレベーター, 南部には滋賀県立農業大学校が存在する。

各視点に対応する道路の全長の計測結果は, 図一4のようにな った。500m 以下と $2,500 \mathrm{~m}$ 以上の視点が多く, $500 \mathrm{~m} \sim 2,500 \mathrm{~m}$ の視点はほとんどなかった。最大值は $3,846 \mathrm{~m}$ (R5, R24), 最小 值は $84 \mathrm{~m}$ (R44), 平均值は $2,108 \mathrm{~m}$ であった。また, 両側に固 場のある部分の長さの, 全長に対する割合は, 図-5 のようにな つた。10\%未満の視点が最も多く, 70\%代，80\%代，30\%代，90\% 代と続く結果となった。最大值は 96.4\% (R11, R39), 最小值は 0\% (R1, R2, R3, R4, R21, R22, R23, R24, R26, R27, R28, R44, R45, R46), 平均值は 39.2\%であった。全長は長い が，両側に圃場のある部分の割合が低い視点（R1，R27，R28， R46) もみられた。煵場でない部分には, 牛舎, サイロ, 直売所, ビニールハウスが認められた。
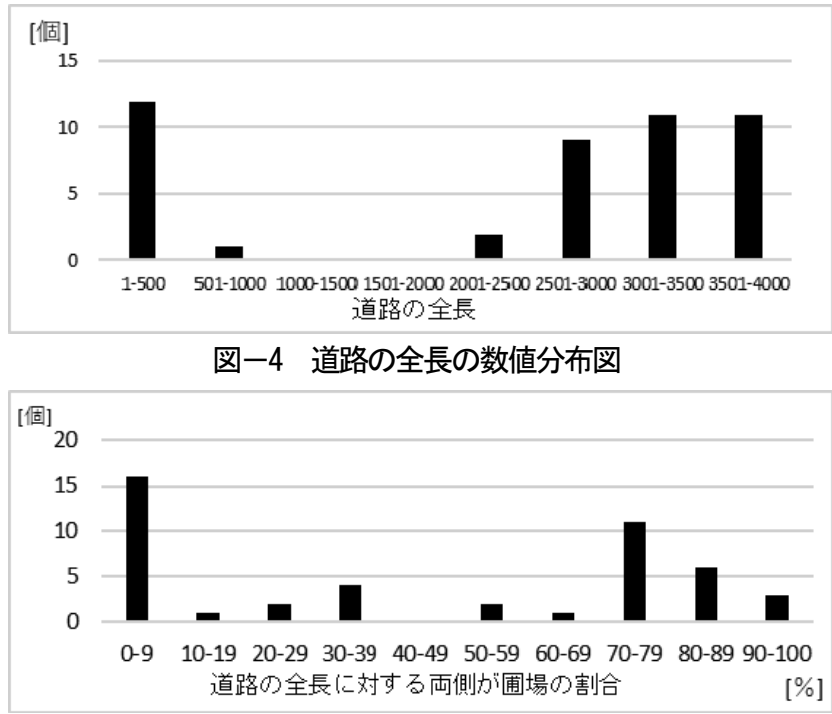

\section{図一5＼cjkstart道路の全長に対する両側が固場の割合の数値分布図}

各視点に対応する排水路の全長の計測結果は，図一6 のように なった。 $500 \mathrm{~m}$ 以下と $3,000 \mathrm{~m}$ 以上の視点が多く, $500 \mathrm{~m} \sim 3,000 \mathrm{~m}$ の視点はほとんどなかった。最大值は 3,668m (W11, W30), 最 小值は $200 \mathrm{~m}$ (W2), 平均值は $1,197 \mathrm{~m}$ であった。また, 両側に 固場のある部分の長さの, 全長に対する割合は, 図一7 のように なった。70\%代の視点が最も多く，80\% 代，50\%代，90\%代， $10 \%$ 未満, と続く結果となった。最大值は $98.0 \%$ (W12, W29), 最小值は $0 \%(\mathrm{~W} 1, \mathrm{~W} 21, \mathrm{~W} 22)$, 平均值は $46.1 \%$ であった。 圃場でない部分には, 牛舎, サイロ, 直売所, ビニールハウスが 認められた。また, 現地踏査や地図読み取りの結果, 大中の湖干 拓地周囲の地理的状況について以下のことがわかった。北部堤防 の北側には琵琶湖の湖水面が広がっていた。東部堤防の東側には 

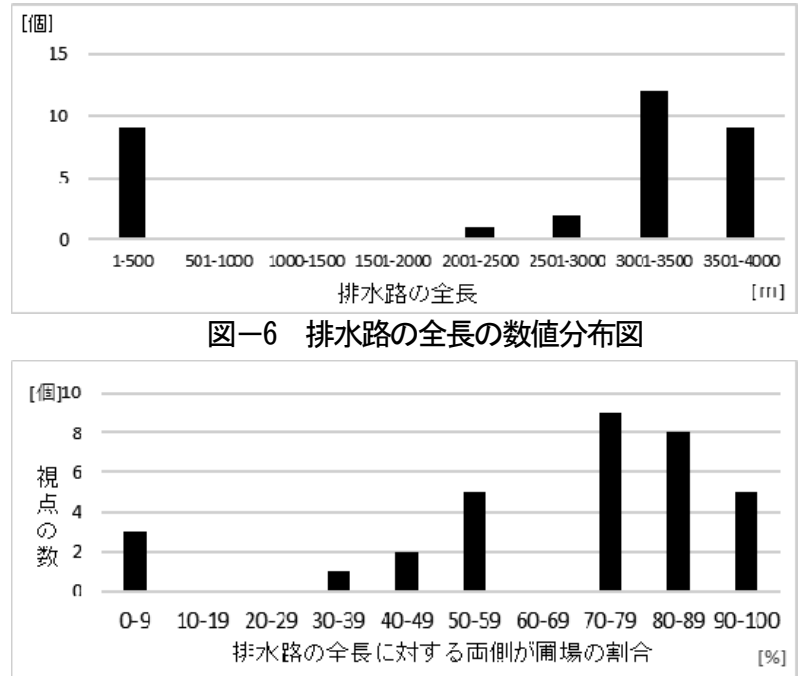

図-7＼cjkstart排水路の全長に二対する両側か涸場の割合の数值分布図

大同川が流れ，その対岸には圃場が広がり集落が点在していた。 南部堤防の南側には小中の湖干拓地の圃場と西の湖の湖水面が広 がり，安土山（標高 198m）や繖山（標高 433m）の山塊が存在 していた。西部堤防の西側は奥島山（標高 $272 \mathrm{~m}$ ) や長命寺山（標 高 $333 \mathrm{~m} ）$ の山塊で占められ，西側には平地がほとんどないこと がわかった。

\section{（2）干拓地や周囲の地形に関わる立体構成}

各視点における堤防の標高を計測したところ, 最小值は $85.4 \mathrm{~m}$ (W15)，最大值は 88.3m（R43），平均值は $86.4 \mathrm{~m}$ であった。 また，各視点に対応する道路の最高点は $85.5 \mathrm{~m} \sim 88.3 \mathrm{~m}$ ，最低点 は 81.9m〜86.0m であった。道路の最高点の值が堤防の標高と同 じなのは，図一8 の模式図に示寸ように，道路が堤防にすりつい ているためである。さらに，排水路の最高点は $82.2 \mathrm{~m} \sim 84.2 \mathrm{~m}$, 最低点は $80.4 \mathrm{~m} \sim 82.7 \mathrm{~m}$ であった。各視点における堤防の標高か ら, 道路および排水路の最低点の標高を差し引いた比高を求めた ところ，それぞれ図-9，10のようになった。

次に，計測した道路および排水路の最高点と最低点の標高に基 づき，道路および排水路の勾配を算出した。道路については，図 -8 の模式図に示すように, 道路が堤防にすりついているため, 道路が堤防の法面に沿うことによって生じる勾配と，干拓地内に おける勾配の 2 通りある。よって, 図一 8 に示寸ように前者を A, $\mathrm{D}$ 区間，後者を $\mathrm{B} ， \mathrm{C}$ 区間として勾配を算出した。なお，排水路 については始点が堤内にあり A，D 区間は存在せず，B，C 区間 の夕勾配を算出した。道路の勾配は，A 区間が最大值- $19.14 \%$, 最小值 $-1.38 \%$, 平均值- $5.27 \%$, B 区間が最大值- $0.71 \%$, 最小值 $0 \%$, 平均值 $-0.12 \%, \mathrm{C}$ 区間が最大值 $0.64 \%$ ，最小值 $0.03 \%$ ，平 均值 $0.15 \%$, D区間が最大值 $16.66 \%$, 最小值 $0.72 \%$, 平均值 $4.99 \%$ であった。排水路の公配は, B 区間が最大值- $0.49 \%$, 最小值- $0.02 \%$, 平均值 $-0.11 \%$, C 区間が最大值 $0.77 \%$, 最小值 $0.07 \%$, 平均值 $0.23 \%$ であった。図一 8 より, 道路およひ排水路ともに, 中央の 幹線排水路を境に傾斜の向きが逆転している。アイストップが各 視点の軸線上に有るかどうか把握したところ, 表一 1 に示すよう に，有った視点が 22 ヶ所，無かった視点が 57 ヶ所であった。干 拓地内のアイストップには，建物，樹木，山塊があった。視点か らアイストップまでの距離は, 道路の場合, 最大值 $1,865 \mathrm{~m}$, 最 小值 $80 \mathrm{~m}$, 平均值 $553 \mathrm{~m}$, 排水路の場合，最大值 $927 \mathrm{~m}$ ，最小值 $72 \mathrm{~m}$, 平均值 $522 \mathrm{~m}$ であった。干拓地内にアイストップが無かっ た 57 ヶ所について，軸線を干拓地外に延長して調べたところ， 干拓地外のアイストップには，建物，樹木，山塊があった。視点

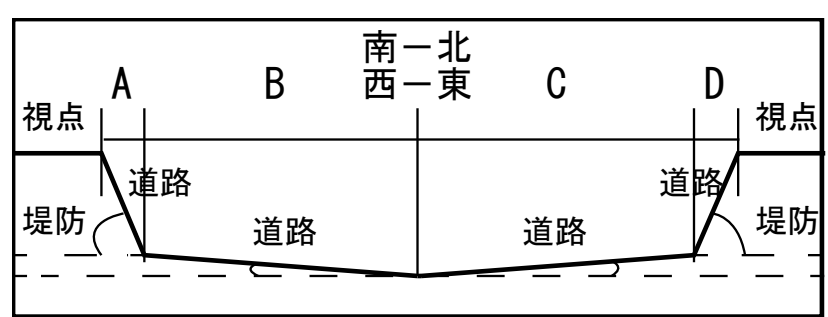

図－8 干拓地の道路の断面模式図

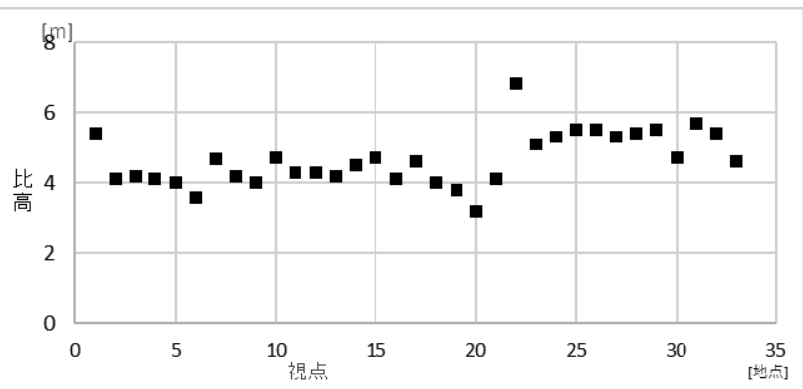

図-9 道路の最低点に対する堤防の比高

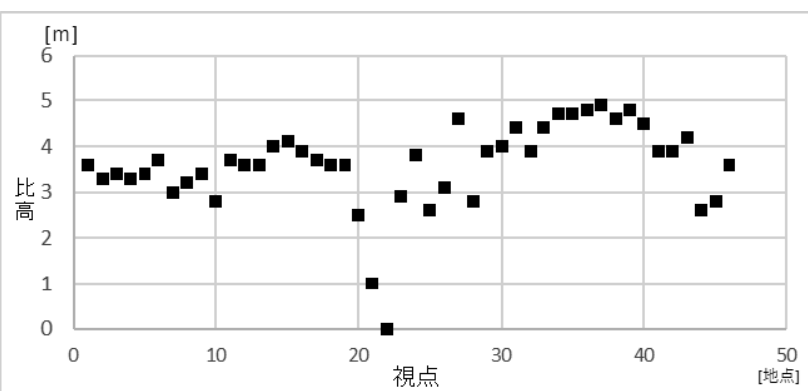

図一10 排水路の最低点に対する堤防の比高

から干拓地外のアイストップまでの距離は, 道路の場合, 最大值 $10,687 \mathrm{~m}$, 最小值 $2,202 \mathrm{~m}$, 平均值 $4,482 \mathrm{~m}$, 排水路の場合, 最大 值 $10,959 \mathrm{~m}$ ，最小值 $2,743 \mathrm{~m}$ ，平均值 $4,978 \mathrm{~m}$ であった。

\section{（3）堤防上から眺望される景観の構成}

各視点における写真をトレースし, 景観の構成を分析したとこ ろ, 軸線の要素, 軸線が見通せる程度, 軸線の両側における要素 の配置に，以下のような違いが認められた。

1）軸線の要素による違い

図-11 の A は道路, B は排水路を軸線とする眺望景観のトレ 一ス結果である。道路の場合, 路面自体が手前から奥に向かって 幅が狭くなり，画面上は台形を呈する。一方，排水路の場合，水 路自体の幅の変化は道路ほど顕著ではなく，画面上は線形を呈す る。排水路の両側にある法面の荒地が，道路と同様に手前から奥 に向かって幅が狭くなり，画面上は台形を呈する。A，B に該当 する視点は，それぞれ 31 ヶ所，21 ヶ所であった。

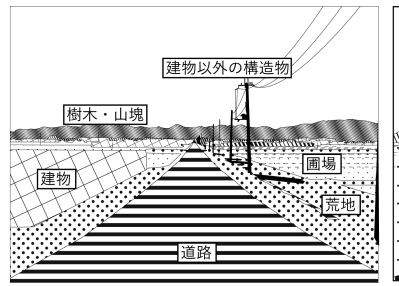

A 道路 (R20)

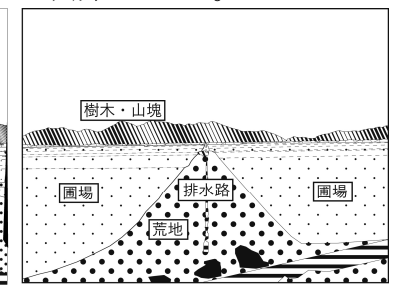

B 排水路 (W2 5)
図-11 眺望景観のトレ一ス結果の例

2）軸線が見通せる程度の違い

前述の $\mathrm{A}, \mathrm{B}$ に該当する視点 31 ヶ所, 21 ヶ所では, 図一 11 の トレース結果に現れているように, 視点から干拓地の対岸まで, 


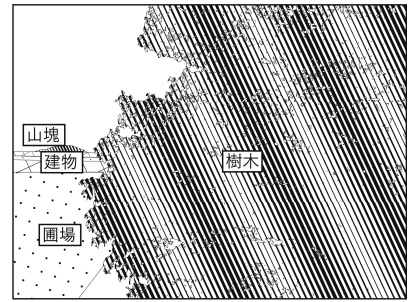

C 樹木による遮蔽 (W1 7)

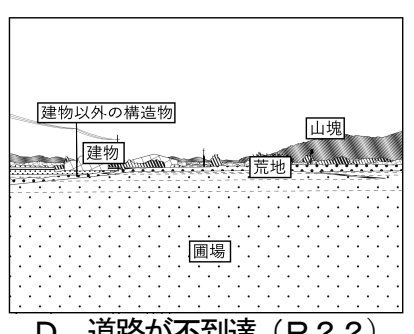

D 道路が不到達 (R 2 2)

レース結果の例

軸線が見通せるように続いていた。それら以外の 27 ヶ所では, 視点から干拓地の対岸まで軸線が続いていなかった。図-12のC は，地図上では道路が堤防まて到達しているが，樹木などにより 視界が遮られている場合である。また，図一12の D は，地図上 において道路が堤防にまで到達しておらず，道路の延長と堤防の 交点に視点を設定した場合である。 C，D侅当する視点は，そ れぞれ 12 ケ所, 15 ケ所であった。

\section{3）軸線の両側における要素の配置の違い}

前述の A，B に該当寸る視点 31 ヶ所，21 ヶ所の中には，図一 13 のトレース結果に現れているように, 道路の路肩に電柱が並ぶ 場合や，道路と固場の間に用水路の樋門が存在寸る場合が認めら れた。電柱や樋門は, 両側の圈場を部分的に遮蔽するものの，電 柱や樋門の隙間から固場が見えている。一方, 図一14のトレース 結果に現れているように，軸線の片側，あるいは両側に，建物や それ以外の構造物が戋場のかわりに存在する場合が認められた。

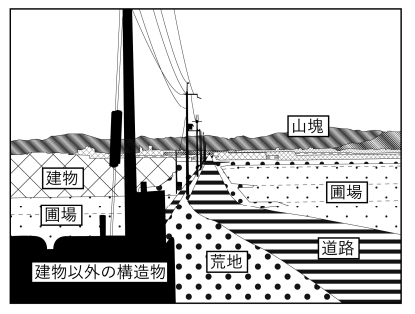

電柱の例（R 12 )

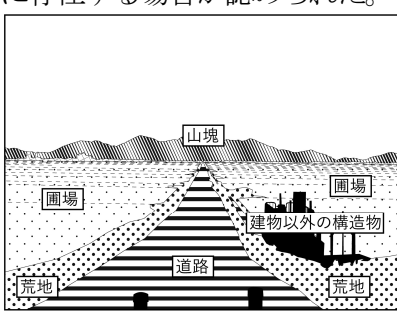

樋門の例 (R3 5)

図-13 眺望景観のトレース結果の例

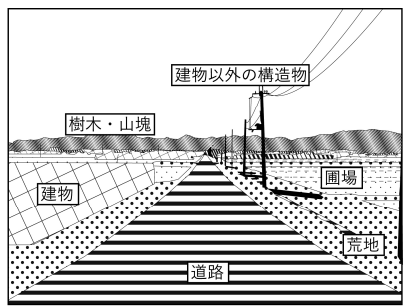

片側に建物の例（R2 O)

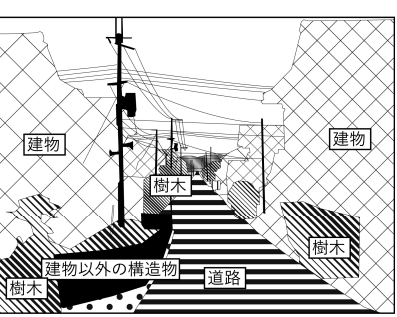

両側に建物の例（R 1 6)

図-14＼cjkstart眺望景観のトレース結果の例

\section{4. 考察}

以上の結果より，堤防上の各視点に対応する道路や排水路が一 定の長さを有すること，および，道路や排水路に対して堤防上の 各視点が一定の比高を有することから，大中の湖干拓地の堤防上 の各視点からは，一定の距離を有する道路や排水路という軸線を 中心とする景観を眺望し得ると言える。実際の眺望景観の分析に おいても，相当の割合で，道路や排水路の干拓地対岸までの見通 しが確認された。また，平面構成の分析より道路や排水路の両側 に围場が存在し，実際の眺望景観でもそれが確認された。したが って, 図一 2 に予想したように, 道路や排水路の軸線を中心とし て，その両側に固場が並ぶという景観の特徵が明らかとなった。 特に，西部堤防や東部堤防上の視点においては，2,500m以上の 長さを有する道路や排水路を望むことができる視点が 55 ヶ所と

表-1 分析結果表

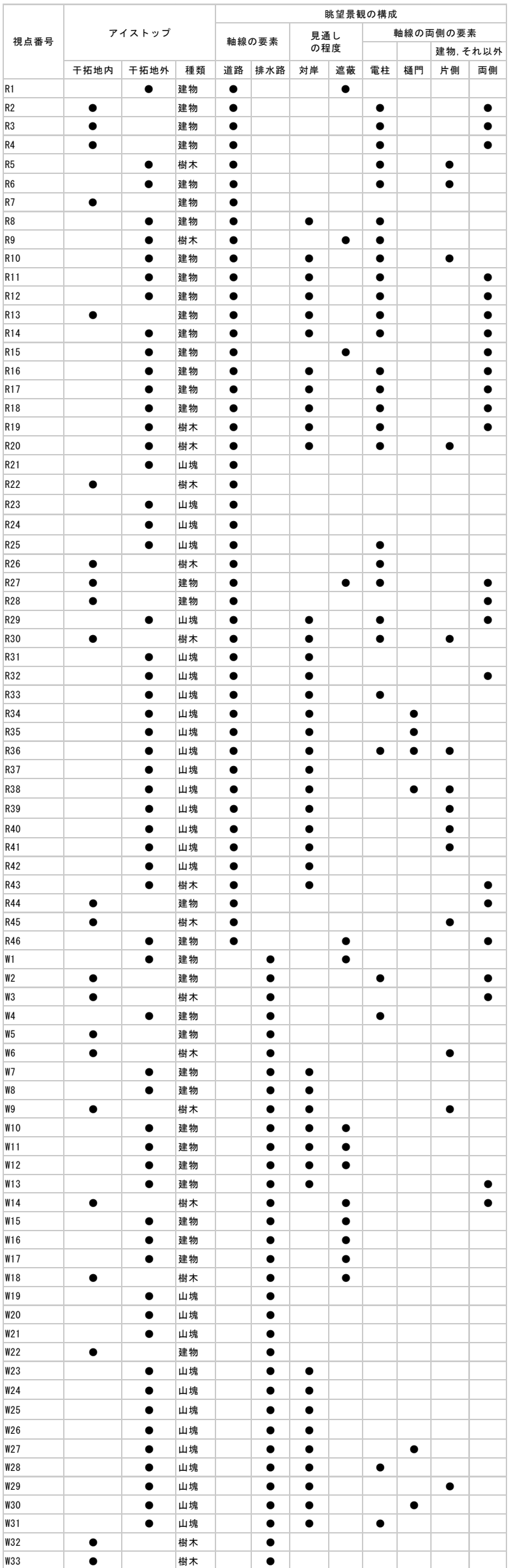


多く存在しており，他の堤防上の視点と比較して，軸線要素を遠 くまで望むことがでさると考えられる。さらに，東部堤防上から は，軸線の先のアイストップとして干拓地外の山塊を望むという 特徵が明らかとなった。

一方，平面構成の分析より，道路や排水路の両側に圃場以外の 要素が存在する部分も，一定の割合で確認された。さらに，実際 の眺望景観でも，軸線要素と圃場の間の電柱や樋門，圃場のかわ りにある建物やそれ以外の構造物の存在が確認された。また，樹 木などの遮蔽物で視界が遮られる場合も確認された。つまり, 前 述した軸線と線対称の景観の特徵は, 干拓地内の建物や之の他の 要素によって弱められることも明らかとなった。

道路の勾配に関しては，堤防上の道路と接続しているため，道 路が堤防の法面に沿うことによって生じる勾配と，干拓地の堤内 における勾配の 2 とおりの勾配が存在している。2 とおりの勾配 が存在しているという点は, 冒頭で述べたフランス式庭園におけ る地形の中折れと共通寸る ${ }^{35)}$ 。排水路は幅が細いが, 道路は比較 的幅があり，周囲の勾配に沿った面的要素として捉えることもで きる。また, 道路および排水路ともに, 中央の幹線排水路を境に, 傾斜の向きが逆転している。つまり，フランス式庭園において視 覚効果を生多出寸地形々同様の勾配変化を，大中の湖干拓地も有 していると言える。

八郎潟干拓地のような景観形成に関わるデザインコードが導入 されなかった大中の湖干拓地だが，以上のような軸線を中心とす る特徽的な景観を有している。これは，水域の周囲に堤防を築い て干陸し，堤内の低い土地に，圃場，排水路，道路，用水路を格 子状に配置する，という干拓地の造成をとおして形成されたもの である。ただし，大中の湖干拓地では，このような景観を形成す るためのデザインコードが無く，軸線や線対称という特徵が建物 やその他の要素によって弱められる状況も生じている。このこと から，大中の湖干拓地においても，景観形成のためのデザインコ ードを導入するなど, 軸線を活かすランドスケープ・デザインが, 景観をはじめとする多面的な価值の向上につながると考えられる。

\section{5. 結論}

大中の湖干拓地の堤防上 79 ヶ所の眺望景観について, 道路や 排水路の軸線を中心に，その両側に圃場が並ぶという景観の特徵 が明らかとなった。また，フランス式庭園の既往研究で指摘され た視覚効果を生み出寸勾配変化を，この干拓地も有していること がわかった。一方，道路や排水路からなる軸線と線対称の景観の 特徵は, 建物やその他の要素によって弱められることもわかった。 さらに，軸線を活かしたランドスケープ・デザインを後から導入 することにより，干拓地の価值を向上させる可能性があることも 判明した。

\section{6. 今後の課題}

本研究では，圃場を一括してとらえて分析しており，圃場の質 的差異を考慮しなかった。例えば，栽培作物の有無や種別，時期 による成長程度の違いなどによって，軸線の両側の圃場の見え方 が異なり，線対称の成立に影響寸る可能性がある。固場の質的差 異を考慮した研究が今後の課題である。また，本研究で明らかに した軸線景観の特徵を，干拓地の多面的価值の 1 つとして位置づ けていくためには, このような景観が人々に与える印象や好まし さについて, 検証を行う必要がある。

謝辞: 本研究は, JSPS 科研費 JP17K08184 の助成を受けたも のである。

\section{補注及び引用文献}

1）農林水産省九州農政局ホームページ: 干拓とは: http://www.maff.go.jp/kyusyu/seibibu/kokuei/18/kantakutoha/index.html : 2018 年 8 月 14 日閲覧

2) 竹内常行 (1975) : 九十九里平野, 特に椿海干拓地の島畑景観について : 地理学嫆平 論 48(7), 445-458

3）五十嵐勉（2000）: 伊万里湾八谷溺の干拓過程と「う水畑」景観一地先干拓の過程 と低湿地農耕技術の視点から- : 低平地研究 $9(8), 13-22$

4）山本明男（2006）: 日本の干拓地 : 農林統計協会

5) 山本奉彦, 吉田好広 (2005) : 幹線排水路における水路護岸の構造検討 : 農業十木 学会誌 73(8), 737-738

6) 川邊炤弘，松井久一 (2006) : 新堀川潮止水門の景観を配慮した構造検討について : 農業十木学会誌 74(4), 339-340

7）松下浩，田中利浩（2007）：軟弱地盤における周辺景観を配慮した自然石積み護 岸: 農業十木学会誌 $75(5), 420-421$

8）松本仁，今西覀友美，今西純一，森本幸裕 (2012) : 巨椋池干拓地およびその周辺 地域の現存植生について : 景観生態学 16(2), 79-88

9) 栗山知士 (2017) : 秋田県大潟地域の気候景観をジオパークに: 日本地理学会発表 要旨集 $2017 \mathrm{~s}(0), 100072$

10) 北條壽 (1968)：八郎湖岸農漁村の変貌 : 地理学評論 41(3), 180-190

11）内湖とは, 浜堤や砂州で琵琶湖と隔てられた水深 $1 \sim 2 \mathrm{~m}$ の平底水域のことである。 西野麻知子 (2007) : 第 1 章琵琶湖のあらまし一内湖 : 琵琶湖ハンドブック（滋賀 県 琵琶湖環境部(環境政策課), 30-31

12）佐藤治雄, 狩屋桂子，前中久行（1996）：琵琶湖湖岸 2 集落における景観と生活の 変化: ランドスケープ研究 59(5), 109-112

13）佐野静代 (2003) : 琵琶湖岸内湖周辺地域における伝統的環境利用システムとその 崩壊 : 地理学論評 76(1), 19-43

14）小沢晴司 (2012) : 琵琶湖国定公園の成立と内湖干拓との関係性に関する考察: ラ ンドスケープ研究 (オンライン論文集) 5, 5-16

15）石田頼房 (1962)：八郎潟干拓地新農村建設計画 : 建築杂隹訫 77(918), 637-641

16）石田頼房, 井手久登, 浦良一 (1978): 八郎潟干拓地新農村集落計画の計画意図と 事後評価 : 都市計画 $100 ， 41-44$

17）浦良一，木村儀 (1976) : 大潟村と農村計画 : 農業十木学会誌 44(5), 299-304

18) 前掲書 14)

19）滋賀県 (2013) : 内湖再生全体ビジョン〜価值の再発見から始まる内湖機能の再生 $\sim$ (資料編), $1-2$

20）琵琶湖干拓史編さん委員会編（1970）: 琵琶湖干拓史

21）承水溝とは，干拓地外周の堤方の外側に設けられた水路のことである。前掲書 20)

22) 平剛直樹 (2016) : ヴォー・ル・ヴィコント庭園の立体構成と平面構成及び構成物 による視覚効果の創出技術 : ランドスケープ研究 79(5), 397-402

23）平岡直樹 (2018) : ヴェルサイユ宮殿庭園の立体構成と平面構成及び構成物による 視覚効果の創出技術 : ランドスケープ研究(オンライン論文集) 81(5)，443-448

24）岡田昌彰, 薮内慎太郎 (2008) : 昭和初期に竣工した京都児童公園の空間構造に関 する研究 : ランドスケープ研究 71(5), 663-668

25）平岡直樹 (2009) : 都市軸とヴィスタからみる都市公園モン・デザールのデザイン 原理 : 都市計画論文集 44(3), 895-900

26）藤田裕翤 (2017)：「堺大絵図」に反映された堺の景観と都市機能（元禄『堺大絵 図』に示された堺の都市構造に関寸る総合的研究）国立歴史民俗博物館研究報告 204, 101-119

27) 前掲書 22)

28) 前掲書 25

29）中国四国農政局 : 笠岡湾干拓事業〜明日を拓く大地と水〜 : http://www.maff.go.jp/chushi/kj/tyutyo/photogallery.html:2018 年 12 月 7 日閲覧 30) 前掲書 22), 23)

31）地理院地図（電子国土Web）: http://maps.gsi.go.jp/ : 2018 年 8 月 15 日閲覧

32）国土地理院 : 基盤地図情報サイト : http://www.gsi.go.jp/kiban/ : 2018 年 8 月 15 日閲覧

33）撮影にはPENTAX K-01 を使用した。人間の視野に近い画角となるよう， $22 \mathrm{~mm}$ （フルサイズ換算で $35 \mathrm{~mm}$ ）にレンズの焦点距離を統一した。

34) 前掲書 22)

35) 前掲書 20) 